\title{
XRCC4 c.1394G $>$ T Single Nucleotide Polymorphisms and Breast Cancer Risk among Filipinos
}

\author{
Julius Adrie Garcia ${ }^{1,2 *}$, Noel Angelo Kalacas ${ }^{1,2}$, Teresa Sy Ortin ${ }^{1,3}$, Maria Cristina \\ Ramos $^{1,2,4}$, Pia Marie Albano ${ }^{1,2,4}$
}

\begin{abstract}
Background: The identification of cancer-associated single nucleotide polymorphisms (SNP) and mutation genes is a promising approach in recognizing individuals who are at risk of developing cancer. Hence, this study was conducted to determine the association between XRCC4 c.1394G $>T$ SNP and breast cancer development among Filipinos. Methods: Genotyping for XRCC4 c.1394G $>T$ SNP was performed on breast cancer patients (n=103) and their age- and sex- matched clinically healthy controls $(\mathrm{n}=103)$ by polymerase chain reaction - restriction fragment length polymorphism. Results: Significant difference in genotype $(\mathrm{p}=0.007)$ and allele $(\mathrm{p}=0.003)$ frequencies in XRCC4 c.1394G $>T$ was observed between the breast cancer cases and controls. Carriers of the XRCC4 c.1394 G>T genotype were observed to have significantly higher risk of developing breast cancer compared to individuals with $\mathrm{T} / \mathrm{T}$ genotype $(\mathrm{OR}=2.67,95 \% \mathrm{CI}: 1.36-5.25) . X R C C 4 \mathrm{c} .1394 G>T$ combined with passive smoking may also significantly increase risk of breast cancer $(\mathrm{OR}=14.73 ; 95 \% \mathrm{CI}=9.88-18.86)$. Conclusion: $X R C C 4$ c. $1394 G>T$ may be associated with breast cancer development among Filipinos.
\end{abstract}

Keywords: XRCC4 SNP- breast cancer- PCR-RFLP- Filipinos

Asian Pac J Cancer Prev, 20 (4), 1097-1101

\section{Introduction}

Breast cancer remains the leading cause of cancer among women worldwide (Sassi et al., 2013). Epidemiological studies show that breast cancer is a multifactorial disease associated with exposure to ionizing radiation, tobacco smoking, alcohol consumption, and use of hormones or oral contraceptives (Dumitrestcu et al., 2005). Furthermore, it is widely established that breast cancer could result from a series of genetic alterations that disrupt the normal mechanism which controls cell proliferation, differentiation, apoptosis, and genomic stability ( $\mathrm{Wu}$ et al., 2008). To counterbalance the detrimental effects of DNA damage, cells have established a dedicated DNA repair system, which can be classified into few distinct mechanisms based on the degree of lesion in the DNA (Bau et al., 2011).

The most biologically perilous types of DNA damage are called the double strand breaks (DSBs). A single unrepaired double strand break is reasonable to induce cell death. These events have been linked with the progress of many types of cancer or other genomic defects (Dexheimer, 2013). The two important mechanisms in DSBs are (1) homologous recombination (HR) and (2) non-homologous end-joining (NHEJ). The two repair systems require a different necessity for a homologous template DNA and also the fidelity of DSB repair. HRdirected repair is an error-free mechanism because it utilizes the genetic information confined in the undamaged sister chromatid as a template (Li and Heyer, 2008). On the other hand, NHEJ is error-prone and involves elimination of DSBs by direct ligation of the broken ends. In all phases of the cell cycle, NHEJ is the principal pathway in mammalian cells while HR is constrained to the late $\mathrm{S}$ and G2 phases (Lieber, 2010).

Several studies have shown that some genetic variants of DNA repair genes, such as the X-ray cross-complementing group 4 (XRCC4) gene are associated with breast cancer pathogenesis (Chiu et al., 2008). The XRCC4 gene which encodes for XRCC4 protein is involved in non-homologous end joining (NHEJ) mechanism critical in double strand break repair (West et al., 2000). The XRCC4 protein helps in repairing the DNA double-strand breaks by stimulating the ligation of non-complementary and complementary DNA ends using XRCC4 ligases (Ming- Zhonget al., 2015). Furthermore, this protein plays a pivotal role in the completion of VDJ recombination in order to generate antigen receptors that can collectively recognize different types of molecules (De Fazio et al., 2002).

${ }^{1}$ The Graduate School, ${ }^{2}$ Research Center for the Natural and Applied Sciences, ${ }^{4}$ College of Science, University of Santo Tomas, ${ }^{3}$ University of Santo Tomas Hospital, Benavides Cancer Institute, Manila, Philippines. *For Correspondence: julius_garcia5@yahoo.com 
Meta-analyses have shown the association of polymorphisms in XRCC4 gene specifically the $\mathrm{G}>\mathrm{T}$ variant with increase in breast cancer risk among Asians and Caucasian, notably in Chinese, Korean, and American populations (Fu et al., 2003; Lee et al., 2005; Han et al., 2009). Furthermore, numerous studies have reported that SNP in the XRCC4 gene is associated with risk of developing breast (Bau et al., 2004), skin (Han et al., 2004), gastric (Chiu et al., 2008), liver (Mederacke et al., 2013), and oral cancer (Yen et al., 2008). However, it must be noted that their findings were also race-specific. Hence, this study is the first to present the possible association of XRCC4 (c.1394G>T) polymorphism with the risk of breast cancer among Filipinos.

\section{Materials and Methods}

\section{Study Population}

Filipino patients, 18 years old and above, with histologically confirmed breast cancer, either newly diagnosed, receiving treatment, or in remission, seen at the University of Santo Tomas Hospital (USTH), Manila between December 2015 to April 2016, were recruited for the study. The cancer patients (cases) were age- $( \pm 2$ years) and sex-matched with volunteer controls who were assessed by a physician collaborator to be clinically healthy and not suspected to have any type of malignancy. Both cases and controls were asked to accomplish through interview a standardized questionnaire inquiring on their risk factors (diet, alcohol and tobacco use, medical history, family history of cancer, reproductive health, environmental and psychological factors, and sedentary behaviour). Five (5) $\mathrm{mL}$ peripheral blood collected from the participants were immediately stored at $-80^{\circ} \mathrm{C}$ until molecular analysis. Clinical data of the cases (age at cancer diagnosis, tumor site, tumor grade, TNM stage, and treatment received) were retrieved from clinical records and histopathology reports.

Ethical clearance was obtained from the Institutional Review Board (Protocol Reference No. IRB-MD-09-2015-133) of USTH and all participants gave their written informed consent.

\section{Genotyping}

Genomic DNA was isolated from the blood samples of all study participants using ReliaPrep ${ }^{\mathrm{TM}}$ Blood gDNA Miniprep System (Promega, USA) following the manufacturer's protocol. All samples were genotyped in triplicate with consistent results to confirm that the genotypes have no mixture of germline and somatic mutations. The genotype at the polymorphic locus of $X R C C 4$ c. $1394 G>T$ was analyzed by polymerase chain reaction - restriction fragment length polymorphism (PCR-RFLP), and further processed as described (Chiu et al., 2008a, Ming-Zhong et al., 2015) but with minor modifications with the annealing temperature and duration of digestion.

A single PCR reaction comprised of a $20 \mu$ total volume of $10 \mu \mathrm{l}$ of PCR master mix ( $20 \mathrm{mM}$ Tris-HCl, $\mathrm{pH}$ $8.3,50 \mathrm{mM} \mathrm{KCl}, 1.5 \mathrm{mM} \mathrm{MgCl} 2,0.2 \mathrm{mM}$ of each dNTPs, $2.5 \mathrm{mM}$ U Taq DNA polymerase), $0.5 \mu \mathrm{l}$ each of $0.25 \mu \mathrm{M}$ forward and reverse primers, $7 \mu$ nuclease free water, and $2 \mu \mathrm{l}$ DNA (89 $\mathrm{ng} / \mu \mathrm{l})$. Target gene was amplified using the primers 5'-GATGCGAACTCAAGATACTGA-3' (forward) and 5'-TGTAAAGCCAGTACTCAAATT-3' (reverse) under the following conditions: initial cycle at $94^{\circ} \mathrm{C}$ for $5 \mathrm{~min} ; 40$ cycles of $94^{\circ} \mathrm{C}$ for $30 \mathrm{~s}, 52.8^{\circ} \mathrm{C}$ for $30 \mathrm{~s}$, and $72^{\circ} \mathrm{C}$ for $30 \mathrm{~s}$; and a final extension at $72^{\circ} \mathrm{C}$ for $10 \mathrm{~min}$. PCR products were digested overnight with HincII at $37^{\circ} \mathrm{C}$. The digested amplicons were subjected to $12 \%$ polyacrylamide gel electrophoresis for $60 \mathrm{~min}$ at $100 \mathrm{~V}$ and viewed under a UV transilluminator. Expected fragment sizes were as follows: T/T: $300 \mathrm{bp} ; \mathrm{G} / \mathrm{G}: 200$, 100; G/T: 300, 200, and 100 (Ming-Zhong et al., 2015).

\section{Statistical Analysis}

To ensure that the controls used were representative of the general population and to exclude the possibility of genotyping error, the deviation of the genotype frequency of XRCC4 SNP in the control subjects from those expected under the Hardy-Weinberg equilibrium was assessed using the goodness-of-fit test. Pearson's Chi-square test or Fisher's exact test (when the expected number in any cell was less than five) were used to compare the distribution of the XRCC4 genotypes between cases and controls. Epidemiologic risk factors associated with the genotypes were estimated as odds ratio (ORs) and 95\% confidence intervals (CIs) using unconditional logistic regression. Data was recognized as significant when the statistical p-value was less than 0.05 . All statistical tests were performed using SAS, Version 9.1.3 (SAS Institute Inc., Cary, NC, USA) on two-sided probabilities.

\section{Results}

A total of 206 samples (103 histologically confirmed breast cancer cases matched with 103 clinically healthy controls) were included in this study. Majority of the cases were 41 to 50 years old, had either well-differentiated (G1) or moderately-differentiated (G2) tumor, and were in their early stage of cancer (Tis, T1, or T2) at the time of diagnosis (Table 1).

Results show that genotypic $(\mathrm{p}=0.007)$ and allelic $(\mathrm{p}=0.003)$ distribution pattern of XRCC4 c.1394G $>T$ were significantly different between breast cancer cases and healthy controls. It appears that $\mathrm{G} / \mathrm{T}$ genotype $(\mathrm{OR}=2.67,95 \% \mathrm{CI} 1.36-5.25)$ is associated with breast cancer among Filipinos (Table 2). Moreover, cases who were exposed to passive smoking, whether carrying the XRCC4 G/T (OR=14.73, 95\%CI 9.88-18.86) or $\mathrm{T} / \mathrm{T}$ $(\mathrm{OR}=4.55,95 \% \mathrm{CI} 2.29-9.04)$ genotype, had increased risk for breast cancer (Table 3). Meanwhile, individuals carrying the $\mathrm{T} / \mathrm{T}(\mathrm{OR}=0.39,95 \% \mathrm{CI} 0.18-0.85)$ genotype and were also alcohol users seem to have lower risk of developing breast cancer compared to those carrying the G/T genotype (Table 4).

\section{Discussion}

Previous studies have associated the trinucleotide repeat polymorphism (CAGn) in the exon 1 of the androgen receptor gene (AR) (Liede et al., 2003) and 
Table 1. Demographic and Clinical Characteristics of Breast Cancer Patients

\begin{tabular}{|c|c|c|}
\hline Characteristic & $\mathrm{n}=103$ & $\%$ \\
\hline \multicolumn{3}{|l|}{ Sex } \\
\hline \multicolumn{3}{|l|}{ Male } \\
\hline \multicolumn{3}{|l|}{ Female } \\
\hline \multicolumn{3}{|l|}{ Age at initial diagnosis } \\
\hline$<50$ & 47 & 45.63 \\
\hline$\geq 50$ & 56 & 54.37 \\
\hline \multicolumn{3}{|l|}{ Tumor grade } \\
\hline Grade cannot be assessed & 12 & 11.65 \\
\hline Well-differentiated & 34 & 33.01 \\
\hline Moderately-differentiated & 35 & 33.98 \\
\hline No data available & 22 & 21.36 \\
\hline \multicolumn{3}{|l|}{ Tumor stage } \\
\hline Primary tumor cannot be evaluated & 8 & 7.77 \\
\hline Tis, $\mathrm{T} 1$, and $\mathrm{T} 2$ & 52 & 50.49 \\
\hline $\mathrm{T} 3$ and $\mathrm{T} 4$ & 33 & 32.04 \\
\hline No data available & 10 & 9.71 \\
\hline \multicolumn{3}{|l|}{ Treatment received } \\
\hline None & 10 & 9.71 \\
\hline Immunotherapy & 15 & 14.56 \\
\hline Surgery & 4 & 3.88 \\
\hline Radiation therapy & 12 & 11.65 \\
\hline Chemotherapy & 21 & 20.39 \\
\hline Surgery and chemotherapy & 8 & 7.77 \\
\hline Surgery and radiation therapy & 9 & 8.73 \\
\hline Chemotherapy and radiation therapy & 4 & 3.88 \\
\hline $\begin{array}{l}\text { Surgery, chemotherapy, radiation } \\
\text { therapy }\end{array}$ & 17 & 16.51 \\
\hline No data available & 3 & 2.91 \\
\hline
\end{tabular}

mutations in $B R C A 1$ and $B R C A 2$ (De Leon Matsuda et al., 2002) with breast cancer among Filipino women. In contrast, variants of the GSTM1 and GSTT1 genes were not found to be risk factors for breast cancer development among the same population (Kalacas et al., 2019). Thus, identifying genes associated with cancer development continues to be a major goal of current research.

$X R C C 4$, which plays a role in both non-homologous end joining and completion of the $\mathrm{V}(\mathrm{D}) \mathrm{J}$ recombination, is among the genes that have been associated with various types of cancer (Krupa et al., 2011). The XRCC4 c. $1394 G>T$, a mutation which lies at the coding region of the XRCC4 gene, might cause an alteration in the amino acid sequence of the XRCC4 protein (Kabziński et al., 2015). This alteration might affect the function of XRCC4 protein in stabilizing the DNA ligase IV which is a crucial part in double strand break repair (Ming-zhong et al., 2015).

This study shows that heterozygous $G / T$ genotype of $X R C C 4$ c. $1394 G>T$ is associated with breast cancer in selected Filipino population. Similarly, XRCC4 c. $1394 G>T G / T$ genotype has been associated with breast, gastric, and prostate cancers among Taiwanese (Chiu et al., 2008) and colorectal cancer among Iranians (Emami et al., 2015). In contrast, the $X R C C 4$ c. $1394 G>T G / T$ genotype was not associated with urinary bladder cancer among the Indians. Besides, the $G / G$ genotype was associated with reduced risk for urothelial bladder in this population (Mittal, et al., 2012). In the current study, the $T / T$ variant of $X R C C 4$ c. $1394 G>T$ was associated with reduced risk for breast cancer.

The present study also considered the combined effect of the genotype variants of XRCC4 c. $1394 G>T$ with clinical and epidemiologic risk factors. Among cases carrying the $G / T$ genotype, those exposed to passive smoke had higher risk of breast cancer compared to active
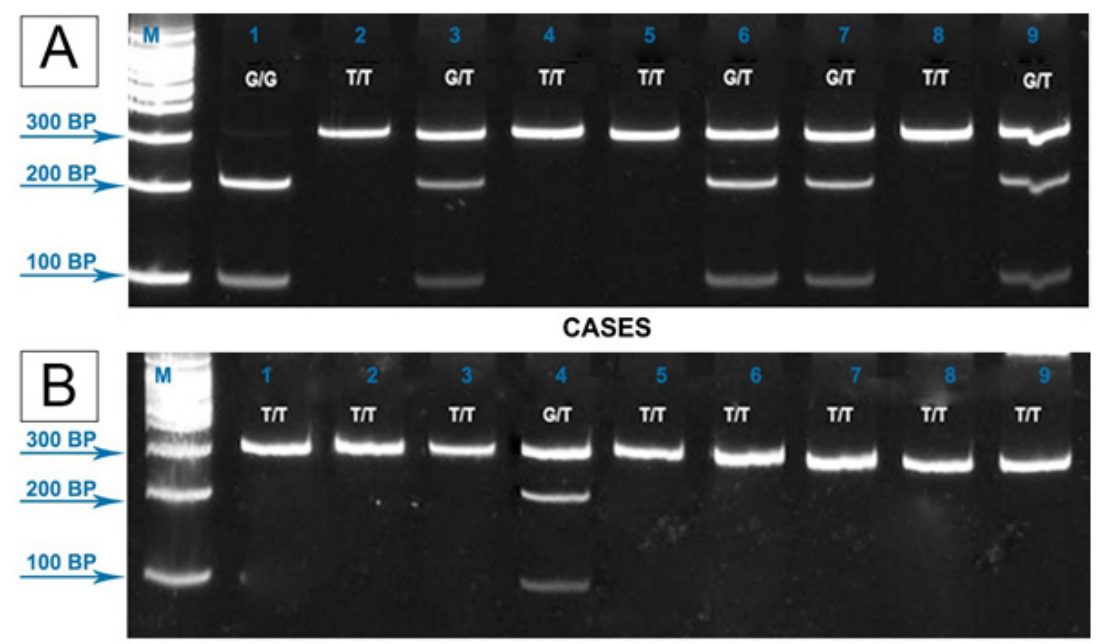

CONTROL

Figure 1. Representative Results for XRCC4 c.1394G>T genotyping by PCR-RFLP Method. DNA isolates from breast cancer cases and controls were subjected to PCR-RFLP using HincII enzyme. Expected fragment sizes were as follows: T/T: 300 bp; G/G: 200, 100; G/T: 300, 200, and 100 (Ming-Zhong et al., 2015). A - Representative cases. Lane M: 1000 kb DNA marker; Lane 1: G/G genotype; Lanes 3, 6, 7, and 9: G/T genotype; Lanes 2, 4, 5, and 8: T/T genotype. B - Representative controls. Lane M: 1000 kb DNA marker; Lane 4: G/T genotype; the rest are T/T genotype. 
Table 2. XRCC4 c.1394G>T Genotype and Allele Frequency Distribution among Breast Cancer Cases and Matched Clinically Healthy Controls

\begin{tabular}{|c|c|c|c|c|c|c|c|c|}
\hline \multirow[t]{2}{*}{ Genotype } & \multicolumn{3}{|c|}{ Cases } & \multicolumn{3}{|c|}{ Controls } & \multirow[t]{2}{*}{ p-values } & \multirow[t]{2}{*}{ OR* $(95 \% \mathrm{CI})$} \\
\hline & $\mathrm{n}$ & $\%$ & HWE* & $\mathrm{n}$ & $\%$ & HWE* & & \\
\hline $\mathrm{G} / \mathrm{G}$ & 1 & 0.97 & & 0 & 0 & & & 1 \\
\hline $\mathrm{G} / \mathrm{T}$ & 34 & 33.01 & 0.147 & 16 & 15.53 & 0.392 & 0.007 & 2.67 (1.36-5.25) \\
\hline $\mathrm{T} / \mathrm{T}$ & 68 & 66.02 & & 87 & 84.87 & & & $0.357(0.183-5.25)$ \\
\hline G allele & 36 & 17.48 & & 16 & 7.77 & & & \\
\hline $\mathrm{T}$ allele & 170 & 82.52 & & 190 & 92.23 & & 0.003 & \\
\hline
\end{tabular}

*HWE, Hardy-Weinberg Equilibrium; *OR, Odds Ratio

Table 3. Combined Effect of XRCC4 G/T Genotype with Lifestyle Factor and Family History of Cancer

\begin{tabular}{|c|c|c|c|c|c|c|}
\hline \multirow[b]{2}{*}{ Combination } & \multicolumn{2}{|c|}{ Cases } & \multicolumn{2}{|c|}{ Controls } & \multirow[b]{2}{*}{ p-value } & \multirow{2}{*}{$\begin{array}{c}\text { OR } \\
(95 \% \mathrm{Cl})\end{array}$} \\
\hline & $\mathrm{n}$ & $\%$ & $\mathrm{n}$ & $\%$ & & \\
\hline$X R C C 4 \mathrm{G} / \mathrm{T}$ and alcohol use & 5 & 4.85 & 3 & 2.91 & 0.471 & $1.7(0.3957-7.3102)$ \\
\hline$X R C C 4 \mathrm{G} / \mathrm{T}$ and tobacco use & 2 & 1.94 & 1 & 0.971 & 0.561 & $1.98(0.1803-22.6286)$ \\
\hline$X R C C 4 \mathrm{G} / \mathrm{T}$ and passive smoker & 13 & 12.6 & 1 & 0.971 & 0.001 & $14.73(9.8898-18.8649)$ \\
\hline$X R C C 4 \mathrm{G} / \mathrm{T}$ with history of cancer in immediate family & 9 & 8.74 & 5 & 4.85 & 0.268 & $1.88(0.6067-5.805)$ \\
\hline$X R C C 4 \mathrm{G} / \mathrm{T}$ with history of cancer in extended family & 12 & 11.7 & 5 & 4.85 & 0.076 & $2.58(0.8763-7.6231)$ \\
\hline
\end{tabular}

Table 4. Combined Effect of XRCC4 T/T Genotype with Lifestyle Factor and Family History of Cancer

\begin{tabular}{|c|c|c|c|c|c|c|}
\hline \multirow[b]{2}{*}{ Combination } & \multicolumn{2}{|c|}{ Cases } & \multicolumn{2}{|c|}{ Controls } & \multirow[b]{2}{*}{ p-value } & \multirow{2}{*}{$\begin{array}{c}\text { OR } \\
(95 \% \mathrm{Cl})\end{array}$} \\
\hline & $\mathrm{n}$ & $\%$ & $\mathrm{n}$ & $\%$ & & \\
\hline$X R C C 4 \mathrm{~T} / \mathrm{T}$ and alcohol use & 11 & 10.7 & 24 & 23.3 & 0.016 & $0.39(0.1814-0.8538)$ \\
\hline$X R C C 4 \mathrm{~T} / \mathrm{T}$ and tobacco use & 8 & 7.8 & 9 & 8.7 & 0.81 & $0.88(0.3255-2.3769)$ \\
\hline$X R C C 4 \mathrm{~T} / \mathrm{T}$ and passive smoker & 43 & 41.7 & 14 & 13.6 & $<0.001$ & $4.55(2.2938-9.0492)$ \\
\hline$X R C C 4 \mathrm{~T} / \mathrm{T}$ and history of cancer in immediate family & 17 & 16.5 & 25 & 24.3 & 0.16 & $0.62(0.3099-1.2273)$ \\
\hline$X R C C 4 \mathrm{~T} / \mathrm{T}$ with history of cancer in extended family & 24 & 23.3 & 26 & 25.2 & 0.74 & $0.9(0.4756-1.0719)$ \\
\hline
\end{tabular}

smokers. Inhaled side stream smoke, the main component of second-hand smoke, is about four times more toxic than active smoking as it contains about 69 known carcinogens and more particulate matter pollution that get into the air (Huang et al., 2005).

To the researchers' knowledge, this is the first report on the association of XRCC4 c.1394G>T with breast cancer development among selected Filipinos. Results of this study contribute to existing evidence supporting the hypothesis that polymorphisms in the XRCC4 c.1394G>T gene may influence the functioning of the DNA repair pathway. Despite the small number of participants in this study, the strict age- and sex-match design adds to the reliability of the findings. However, related future studies should screen for other polymorphisms in the XRCC4 gene and other DNA repair genes, and to determine their combined effects with lifestyle risk factors. Furthermore, participants from other parts of the country should be included to accurately represent the Filipino population.

\section{Funding Statement}

This study was supported by research grants from the Department of Science and Technology - Science Education Institute (DOST - SEI) and the Commission on Higher Education (CHED) of the Philippines.
Statement conflict of Interest

The authors declare no conflict of interest

\section{References}

Bau DT, Tsai CW, Wu CN (2011). Role of the XRCC5/ XRCC6 dimer in carcinogenesis and Pharmacogenomic. Pharmacogenomics, 12, 515-34.

Bau D, Fu Y, Chen S, Cheng T, Yu J, Wu P (2004). Breast cancer risk and the DNA double-strand break end-joining capacity of non-homologous end-joining genes are affected by BRCA1 breast cancer risk and the DNA double-strand break end-joining capacity of non-homologous end-joining genes are affected by BRC. Cancer Res, 64, 5013-19.

Chang CH, Chiu CF, Wu HC, et al (2008). Significant association of XRCC4 single nucleotide polymorphisms with prostate cancer susceptibility in Taiwanese males. Mol Med Rep, 1, $525-30$.

Chiu CF, Wang HC, Wang CH, et al (2008a). A new single nucleotide polymorphism in XRCC4 gene is associated with breast cancer susceptibility in Taiwanese patients. Anticancer Res, 28, 267-270.

Chiu CF, Wang CH, Wang CL, et al (2008b). A novel single nucleotide polymorphism in XRCC4 gene is associated with gastric cancer susceptibility in Taiwan. Ann Surg Oncol, 15, 514-8.

De Fazio L, Stansel R, Griffith J, Chu G (2002). Synapsis of DNA ends by DNA-dependent protein kinase. EMBO J, 21, 3192-3200. 
De Leon Matsuda ML, Liede A, Kwan E, et al (2002). BRCA1 and BRCA2 mutations among breast cancer patients from the Philippines. Int J Cancer, 98, 596-603.

Dexheimer T (2013). DNA Repair Pathways and Mechanisms. In L. Mathews, S. Cabarcas, and E. Hurt (Eds.), DNA Repair of Cancer Stem Cells. Dordrecht: Springer Netherlands, pp 19-32.

Dumitrescu PG (2005). Understanding breast cancer risk: Where do we stand in 2005?. J Cell Mol Med, 9, 208-21.

Emami N, Saadat I, Omidvari S (2015). Susceptibility to colorectal cancer and two genetic polymorphisms of XRCC4. Pathol Oncol Res, 21, 881-5.

$\mathrm{Fu}$ Y, Yu J, Cheng T, et al (2003). Breast cancer risk associated with genotypic polymorphism of the nonhomologous end joining genes: a multi-genic study on cancer susceptibility. Cancer Res, 63, 2440-6.

Han J, Haiman C, Niu T, et al (2009). Genetic variation in DNA repair pathway genes and premenopausal breast cancer risk. Breast Cancer Res Treat, 115, 613-22.

Han J, Colditz GA, Samson LD, Hunter DJ (2004). Polymorphisms in DNA double-strand break repair genes and skin cancer risk. Cancer Res, 64, 3009-13.

Hoeijmakers JH (2001). Genome maintenance mechanism for preventing cancer. Nature, 411, 366-74.

Huang WY, Olshan AF, Schwartz SM, et al (2005). Selected genetic polymorphisms in MGMT, XRCC1, XPD, and $\mathrm{XRCC} 3$ and risk of head and neck cancer: A pooled analysis. Cancer Epidemiol Biomarkers Prev, 14, 1747-53.

Kabziński J, Majsterek I, Dziki A, Dziki Ł, Mik M (2015). The role of the XPF gene polymorphism (XRCC4) Ser835Ser in the risk of malignant transformation of cells in the colorectal cancer. Polish J Surg, 87, 83-5.

Kalacas N, Garcia J, Sy-Ortin T, et al (2019). GSTM1 and GSTT1 Genetic Polymorphisms and Breast Cancer Risk in Selected Filipino Cases. Asian Pac J Cancer Prev, 20, 529-35.

Krupa R, Sliwinski T, Wisniewska-Jarosinska M, et al (2011). Polymorphisms in RAD51, XRCC2 and XRCC3 genes of the homologous recombination repair in colorectal cancer-a case control study. Mol Biol Rep, 38, 2849-54.

Lee KM, Choi JY, Kang C, et al (2005). Genetic polymorphisms of selected DNA repair genes, estrogen, and progesterone receptor status, and breast cancer risk. Clin Cancer Res, 11, 4620-6.

Li X, Heyer W (2008). Homologous recombination in DNA repair and DNA damage tolerance. Cell Res, 18, 99-113.

Lieber M (2010). The mechanism of double-strand DNA break repair by the nonhomologous DNA end-joining pathway. Annu Rev Biochem, 79, 181-211.

Liede A, Zhang W, De Leon Matsuda ML, Tan A, Narod SA (2003). Androgen receptor gene polymorphism and breast cancer susceptibility in the Philippines. Cancer Epidemiol Biomarkers Prev, 12, 848-52.

Mederacke I, Hsu CC, Troeger JS, et al (2013). Fate tracing reveals hepatic stellate cells as dominant contributors to liver fibrosis independent of its aetiology. Nat Commun, 4, 1-11.

Mittal RM, Gangwar R, Mandal R, et al (2012). Gene variants of XRCC4 and XRCC 3 and their association with risk for urothelial bladder cancer. Mol Biol Rep, 39, 1667 - 75.

Ming-Zhong S, Hui-Xiang J, Zhong-Wei Z, Hao J, Rong Z (2015). Genetic variants of the DNA damage repair genes XRCC4 and RAD51 are associated with susceptibility to esophageal cancer. Clin Res Hepatol Gastroenterol, 39, 379-83.

Qureshi Z, Mahjabeen I, Baig RM, Kayani MA (2014). Correlation between selected XRCC2, XRCC3, and RAD51 gene polymorphisms and primary breast cancer in women in
Pakistan. Asian Pac J Cancer Prev, 15, 10225-9.

Sassi A, Popielarski M, Synowiec E, Morawiec Z, Wozniak K (2013). BLM and RAD51 genes polymorphism and susceptibility to breast cancer. Pathol Oncol Res, 19, 451-9.

Sahu S, Choudhuri T (2013). Lack of association between Bax promoter (-248G\&gt;A) single nucleotide polymorphism and susceptibility towards cancer: Evidence from a Meta-Analysis. PLoS One, 8, p.e77534.

Smith TR, Levine EA, Perrier ND, et al (2003). DNA-repair genetic polymorphisms and breast cancer risk. Cancer Epidemiol Biomarkers Prev, 12, 1200-14.

West CE, Waterworth WM, Jiang Q, Bray CM (2000). Arabidopsis DNA ligase IV is induced by gamma-irradiation and interacts with an Arabidopsis homologue of the double strand break repair protein XRCC4. Plant J, 24, 67-78.

Wood RD, Mitchell M, Lindahl T (2005). Human DNA repair genes. Mutat Res, 577, 275-83.

Wu CN, Liang Sy, Tsai CW, et al (2008). The role of XRCC4 in carcinogenesis and anti-cancer drug discovery. Recent Pat Anticancer Drug Discov, 3, 209-19.

Yen CY, Liu SY, Chen CH, et al (2008). Combinational polymorphisms of four DNA repair genes XRCC1, XRCC2, $\mathrm{XRCC} 3$, and $\mathrm{XRCC} 4$ and their association with oral cancer in Taiwan. J Oral Pathol Med, 37, 271-7.

Zhang Z, Hu W (2011). A single nucleotide polymorphism in $\mathrm{XRCC} 4$ gene is associated with reduced colorectal cancer susceptibility in female. Ying Wen Ban, 26, 85-93.

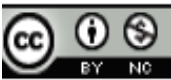

This work is licensed under a Creative Commons AttributionNon Commercial 4.0 International License. 